Article

\title{
Quality Acceptability, Nutritional Composition and Antioxidant Properties of Carrot-Cucumber Juice
}

\author{
Taiwo Ayodele Aderinola * $*$ and Kemi Elizabeth Abaire \\ Department of Food Science and Technology, The Federal University of Technology, Akure PMB 704, Nigeria; \\ kemiabaire@gmail.com \\ * Correspondence: taaderinola@futa.edu.ng; Tel.: +234-7036569677
}

Received: 18 December 2018; Accepted: 11 January 2019; Published: 1 February 2019

\begin{abstract}
Fresh vegetables (carrot and cucumber) were juiced using a juice extractor. The extracted juice was then divided into five varying proportions: A (100\% carrot juice), B ( $80 \%$ carrot, $20 \%$ cucumber), C (70\% carrot, 30\% cucumber), D (50\% carrot, $50 \%$ cucumber) and E (100\% cucumber). The juice blends were then analyzed for proximate, mineral and vitamin compositions. The phytochemical and the antioxidant properties were also determined. The proximate composition result revealed very high moisture (82.03-83.85\%), relatively low carbohydrate (5.23-10.57\%) and very low crude protein (1.75-4.14\%) contents. For the micronutrients, potassium $(14.70-32.10 \mathrm{mg} / 100 \mathrm{~mL})$ and vitamin C (14.48-24.48 mg/100 mL) were more predominant when compared to the other micronutrients that were determined. The $\mathrm{pH}$ was mildly acidic (5.90-6.21) and the Brix value ranged between 3.51 and $7 \%$. The antioxidant result indicated that better bioactivity could be obtained from the blends than the individual juices. While there were no statistically significant differences in the sensory properties of the juices, the $100 \%$ carrot juice was rated higher in all the attributes evaluated. Therefore, it was concluded that a blend of carrot and cucumber at a 50:50 ratio offered comparable nutritional and better antioxidative quality when compared to other blends.
\end{abstract}

Keywords: carrot juice; cucumber juice; juice blends; chemical composition; antioxidant properties

\section{Introduction}

Vegetables are essential components in the human diet providing vital micronutrients such as vitamins (A, B, C, E) and minerals (calcium, potassium, sodium etc.) that are essential for proper growth and development as well as playing other roles in normal body function or metabolism [1-3]. Vegetables can be from various sources such as the leaves, roots or stems of plants. These are good sources of vitamins, minerals, fiber and protein. Common vegetables such as spinach, carrots, onions, tomatoes, cucumbers, etc., are good sources of these essential nutrients. The variety and the deep pigmentations of vegetables also confer on them the ability to offer other benefits $[4,5]$ apart from the common nutrients such as the vitamins and minerals they are mostly known for [6]. For instance, green, yellow and orange pigmented vegetables, such as cabbages, tomatoes, carrots and cucumbers, are rich sources of beta carotene, a precursor of vitamin A [7]. Besides, studies have confirmed the health promoting (antioxidative, anti-inflammatory, anti-cancer, antihypertensive, anti-diabetic) properties of the different polyphenolic compounds which are responsible for these pigmentations.

Cucumber (Cucumis sativus) is an important and popular vegetable of the Cucurbitaceae family. It is reported to be one of the earliest vegetables to be cultivated by man as far back as 5000 years ago [3,5]. Its high moisture content (about 95\%) makes it ideal to promote hydration. The major nutrients and bioactive components in cucumber include vitamin C, A, B6, potassium, magnesium, phosphorus, manganese, flavonoids, beta carotene, lignans and triterpenes which are able to act as antioxidant and anti-inflammatory agents [5]. 
Carrot (Daucus carota) is a small delicious root vegetable. It may be as small as $50 \mathrm{~mm}$ to as long as $150 \mathrm{~mm}$ in length and between 20 and $100 \mathrm{~mm}$ in thickness [5]. It is best known for being a rich source of beta carotene, a precursor of vitamin A [7]. In addition to providing a good content of vitamin and minerals, it is also rich in other phytochemicals such as flavonoids and polyacetylenes which are essential for good health.

Fruit and vegetable juices are high moisture nonalcoholic beverages laden with essential nutrients and able to serve as a good thirst quencher [5]. Previous studies have highlighted the nutritional compositions of fruit and vegetable juices as well as the effects of storage on their shelf life [8-10]. The prevalence of consumption of fresh juices from fruit and vegetables has been attributed to their ability to promote good health due to the different bioactive phytochemicals present in them [5]. Because the nutrients and bioactive components of fruit and vegetables are extracted during juicing, fruit and vegetable juices provide an avenue to derive maximum benefits as more of these essential plants' components-nutrients and other bioactive phytochemicals—can be obtained compared to having to chew the fruit or vegetable that will give a commensurate quantity of the nutrients. With respect to mixed fruit and vegetable juices, besides the improvement in nutritional quality of the juice due to the combination of two or more fruits/vegetable, it has also been confirmed that the organoleptic properties of the juice may be enhanced in some cases $[1,5]$.

Therefore, the objectives of the current study were to evaluate the nutritional composition and antioxidant properties, as well as the quality acceptability, of carrot-cucumber juice through sensory evaluation.

\section{Materials and Methods}

\subsection{Materials}

Fresh carrots and cucumbers were obtained from Sasha Market in Akure, Ondo State, and all the chemicals/reagents used for the analysis were of analytical grade.

\subsection{Method of Preparation of Juice Samples}

Fresh carrots (Daucus carota) and cucumbers (Cucumis sativa) were selected, cleaned, and juiced separately using a juice extractor. The juice was then filtered, pasteurized at $75{ }^{\circ} \mathrm{C}$ for $15 \mathrm{~min}$ and cooled. Thereafter, the juices were divided into five varying proportions as shown in Table 1 :

Table 1. Juice mixing ratio (\%).

\begin{tabular}{ccc}
\hline Samples & Carrot & Cucumber \\
\hline A & 100 & - \\
B & 80 & 20 \\
C & 70 & 30 \\
D & 50 & 50 \\
E & - & 100 \\
\hline
\end{tabular}

\subsection{Analysis of the Smoothies}

The proximate composition (ash, fat, moisture content, protein and carbohydrate) and other analyses such as percentage Brix, $\mathrm{pH}$, viscosity and titratable acidity of the product were carried out using AOAC [11].

\subsection{Determination of Vitamin C Content}

The vitamin $C$ content was determined using ascorbic acid $(0.01 \mathrm{mg} / \mathrm{mL})$ as the reference compound. Two hundred milliliters of the extract was mixed with $300 \mathrm{~mL}$ of $13.3 \%$ trichloroacetic acid (TCA) and $75 \mathrm{~mL}$ of 2,4-dinitrophenylhydrazine (DNPH). The mixture was incubated at $37^{\circ} \mathrm{C}$ for $3 \mathrm{~h}$ and $500 \mathrm{~mL}$ of $\mathrm{H}_{2} \mathrm{SO}_{4}$ was added to the mixture before the absorbance was read at $520 \mathrm{~nm}$ [12]. 


\subsection{Determination of Vitamin A Content}

An amount of $1 \mathrm{~g}$ of the sample was weighed, and then $30 \mathrm{~mL}$ of absolute alcohol and $3 \mathrm{~mL}$ of $5 \%$ potassium hydroxide were added to the sample. Next, the mixture was boiled gently at $50{ }^{\circ} \mathrm{C}$ under reflux (covered with cotton wool and wrapped with foil paper) for $30 \mathrm{~min}$ in a stream of oxygen-free nitrogen. It was rapidly cooled and washed with $3 \times 50 \mathrm{~mL}$ of ether or petroleum ether and vitamin A was then extracted by shaking for $1 \mathrm{~min}$. After complete separation, the lower layer was discarded and the extract was washed with $4 \times 50 \mathrm{~mL}(3 \times 10 \mathrm{~mL})$ of water, mixing particularly cautiously during the first two washes to avoid emulsion formation. The washed extract was evaporated down to approximately $5 \mathrm{~mL}$ and the remaining ether was removed in a stream of nitrogen at room temperature. The residue was dissolved in sufficient isopropyl alcohol to give a solution containing 9-15 units per $\mathrm{mL}$ and the extinctions were measured at $300,310,325$ and $334 \mathrm{~nm}$ with a wavelength of maximum absorption [13].

\subsection{Determination of Mineral Content}

Five grams each of the carrot-cucumber juice samples was heated gently over a Bunsen burner flame until most of the organic matter was destroyed. The sample was further heated in a muffle furnace for several hours until white-grey ash was obtained. The ash material was cooled. About $20 \mathrm{~mL}$ of distilled water and $10 \mathrm{~mL}$ of the dilute hydrochloric acid were added to the ashed material. This mixture was boiled, filtered into a $250 \mathrm{~mL}$ volumetric flask, washed thoroughly with hot water, cooled and then made up to volume. The mineral content of the sample was analyzed using colorimetric or spectrophotometric or titrimetric methods where applicable [11]. The samples were analyzed for sodium $(\mathrm{Na})$, potassium $(\mathrm{K})$, calcium $(\mathrm{Ca})$, iron $(\mathrm{Fe})$ and magnesium $(\mathrm{Mg})$.

\subsection{Determination of Total Flavonoid Content}

The total flavonoid content of the extract was determined using a colorimeter assay developed by Bao [4] with some modifications. An aliquot $(0.2 \mathrm{~mL})$ of the extract was added to $0.3 \mathrm{~mL}$ of $5 \%$ $\mathrm{NaNO}_{2}$ and after $5 \mathrm{~min}, 0.6 \mathrm{~mL}$ of $10 \% \mathrm{AlCl}_{3}$ was also added followed by the addition of $2 \mathrm{~mL}$ of $1 \mathrm{M}$ $\mathrm{NaOH}$, after $6 \mathrm{~min}$, and $2.1 \mathrm{~mL}$ of distilled water. The absorbance was read at $510 \mathrm{~nm}$ against the blank reagent and the flavonoid content was expressed as mg rutin equivalent.

\subsection{Determination of Total Phenolic Content}

The total phenolic content of the extract was determined by the method of Nabavi et al. [14] with some modifications. Two hundred microliters of the extract was mixed with $2.5 \mathrm{~mL}$ of $10 \%$ Folin-Ciocalteau's reagent and $2 \mathrm{~mL}$ of $7.5 \%$ sodium carbonate. The reaction mixture was subsequently incubated at $45^{\circ} \mathrm{C}$ for $40 \mathrm{~min}$ and the absorbance was measured at $760 \mathrm{~nm}$. Garlic acid was used as a standard phenol.

\subsection{Determination of the Radical Scavenging Ability (DPPH)}

The free radical scavenging ability of the extract against DPPH (1,1- diphenyl-2-picryhydrazyl) was carried out using the method of Nabavi et al. [14] with slight modifications. One milliliter of the extract was mixed with $1 \mathrm{~mL}$ of the $0.4 \mathrm{mM}$ methanolic solution of the DPPH, and then the mixture was left in the dark for $30 \mathrm{~min}$ before measuring the absorbance at $517 \mathrm{~nm}$. The control consisted of methanol instead of the sample and the radical scavenging ability of the sample was calculated as:

$$
\% D P P H=\frac{A_{\text {control }}-A_{\text {sample }}}{A_{\text {control }}} \times 100
$$




\subsection{Determination of Ferric Reducing Antioxidant Power (FRAP)}

The reducing property of the extract was determined by measuring $250 \mu \mathrm{L}$ of the sample into test tubes (with distilled water as a blank), and $250 \mu \mathrm{L}$ of $0.02 \mathrm{M}$ phosphate buffer (pH 6.9) was added to it in addition to $250 \mu \mathrm{L}$ of $1 \% \mathrm{~K}_{3}[\mathrm{Fe}(\mathrm{CN})]_{6}$. The mixture was incubated for $20 \mathrm{~min}$ at $50{ }^{\circ} \mathrm{C}$. Thereafter, $250 \mu \mathrm{L}$ of $10 \%$ TCA was added to the mixture, as well as $200 \mu \mathrm{L}$ of $0.1 \%$ freshly prepared $\mathrm{FeCl}_{3}$ (Ferric Chloride) and $1 \mathrm{~mL}$ of distilled water. The absorbance was read at $760 \mathrm{~nm}$. Ascorbic acid $(0.01 \mathrm{mg} / \mathrm{mL})$ was used as the standard.

\subsection{Sensory Evaluation}

The sensory evaluation of samples of the smoothie was carried out by 20 semi-trained panelists comprising of students within the premises of the Federal University of Technology, Akure, using a nine-point hedonic scale where the scores ranged from 'like extremely' (1) to 'dislike extremely' (9). Water was provided for each panelist for mouth rinsing after testing each product so as to avoid the carry-over effect.

\subsection{Statistical Analysis}

The sample measurements were performed in triplicate and the data were analyzed with SPSS version 17 (IBM, Armonk, NY, USA), while the means were separated for significant differences $(p<0.05)$ using Duncan's Multiple Range test.

\section{Results and Discussion}

\subsection{Proximate Composition of the Juice}

The proximate composition of carrot juice, cucumber juice and carrot-cucumber juice is shown in Table 2. Juices are known for their high moisture content which makes them ideal for quenching thirst. Therefore, the high moisture content of the juices, which ranged between $82.03 \%$ and $82.20 \%$, is expected because the raw materials, in particular cucumbers, from which the juices are made, are high in moisture content. The moisture content values obtained in this study are also relatively comparable to the range of $86.04-89.30 \%$ previously reported for carrot-yoghurt juice [7] and also for other fruit juices as reported by Braide et al. [15]. Although the crude protein content is generally low $(1.75-4.80 \%)$, the proximate result also indicated that cucumbers contain significantly higher protein content $(4.14 \%)$ when compared to carrots $(1.75 \%)$. This difference mildly increased the protein content of the mixed beverages accordingly. A previous study on carrots also confirmed their low protein content (1.07\%) [16]. Although this is slightly lower than the value $(1.75 \%)$ obtained in this study, the differences might be due to variations in the levels of maturity, variety and possibly geographical locations. While beverages are mostly cherished and consumed for their thirst-quenching abilities, varied reports also abound on the efforts being made to increase their nutritional quality, specifically, protein content and possibly, improved bioactivity, through the blending of two or more fruits or vegetables $[1,2,17]$. The protein content obtained in this study $(1.75$ to 4.80$)$ is higher than the $0.03-0.53 \%$ reported for soy, carrot and beetroot juice blends [1]. Also moderately significant in the proximate composition of the juice is its carbohydrate content, which ranged between 5.26 and $10.57 \%$. The crude fiber obtained in this study (1.15-1.96) is similar to the value (1.16) previously reported by Olalude et al. [16]. The ash content, an inorganic aspect of foods, gives an indication of the range of mineral elements present in food materials [16]. The total ash content of the juice sample ranged between 0.83 and $1.98 \%$. The ash content obtained is higher than the ranges $(0.38-0.58 \%)$ obtained by Dima et al. [18]. 
Table 2. Proximate composition of carrot-cucumber juice (\%).

\begin{tabular}{ccccccc}
\hline Samples & Crude Fibre & Moisture & Total Ash & Fat & Crude Protein & Carbohydrate \\
\hline A & $1.96 \pm 0.01^{\mathrm{a}}$ & $82.03 \pm 0.06^{\mathrm{e}}$ & $0.83 \pm 0.01^{\mathrm{e}}$ & $2.89 \pm 0.00^{\mathrm{c}}$ & $1.75 \pm 0.01^{\mathrm{e}}$ & $10.57 \pm 0.01^{\mathrm{a}}$ \\
B & $1.66 \pm 0.01^{\mathrm{b}}$ & $83.60 \pm 0.10^{\mathrm{b}}$ & $1.98 \pm 0.01^{\mathrm{a}}$ & $1.79 \pm 0.01^{\mathrm{d}}$ & $3.28 \pm 0.01^{\mathrm{c}}$ & $7.69 \pm 0.00^{\mathrm{c}}$ \\
$\mathrm{C}$ & $1.65 \pm 0.01^{\mathrm{b}}$ & $83.03 \pm 0.06^{\mathrm{c}}$ & $1.01 \pm 0.01^{\mathrm{c}}$ & $1.59 \pm 0.01^{\mathrm{e}}$ & $2.37 \pm 0.01^{\mathrm{d}}$ & $10.38 \pm 0.01^{\mathrm{b}}$ \\
$\mathrm{D}$ & $1.23 \pm 0.01^{\mathrm{c}}$ & $83.85 \pm 0.01^{\mathrm{a}}$ & $0.87 \pm 0.01^{\mathrm{d}}$ & $3.99 \pm 0.00^{\mathrm{a}}$ & $4.80 \pm 0.01^{\mathrm{a}}$ & $5.26 \pm 0.01^{\mathrm{e}}$ \\
$\mathrm{E}$ & $1.15 \pm 0.01^{\mathrm{d}}$ & $82.20 \pm 0.01^{\mathrm{d}}$ & $1.59 \pm 0.01^{\mathrm{b}}$ & $3.71 \pm 0.01^{\mathrm{b}}$ & $4.14 \pm 0.01^{\mathrm{b}}$ & $7.21 \pm 0.01^{\mathrm{d}}$ \\
\hline
\end{tabular}

The data are presented as mean \pm SD. The mean values in the same column with different superscript letters are significantly different $(p \leq 0.05)$. A $=100 \%$ carrot; $B=80 \%$ carrot, $20 \%$ cucumber; $C=70 \%$ carrot, $30 \%$ Cucumber; $\mathrm{D}=50 \%$ carrot, $50 \%$ cucumber and $\mathrm{E}=100 \%$ cucumber juice.

\subsection{The Mineral and Vitamin Compositions of the Juice}

The results of the mineral elements and vitamin compositions of the samples are shown in Table 3. Carrot juice showed greater concentrations of all the minerals tested for in the juice-calcium, magnesium, phosphorus and potassium - than cucumber juice. The concentration of potassium $(14.7-32.10 \mathrm{mg} / 100 \mathrm{~mL})$ is of particular significance when compared to the presence of other minerals in the products. Potassium is an essential constituent of cells and body fluids. It plays vital roles in controlling heart rate and blood pressure [3]. The ranges of the concentration of other minerals in the product are calcium (1.37-3.20), magnesium (0.13-1.40) and phosphorus $(2.40-4.83) \mathrm{mg} / 100 \mathrm{~mL}$. Vitamin $C$ is a water soluble vitamin which also has antioxidant properties. The vitamin $C$ content of the juice ranged between 15.54 and $24.48 \mathrm{mg} / 100 \mathrm{~mL}$ while vitamin A ranged between 1.9 and $5.28 \mathrm{mg} / 100 \mathrm{~mL}$. The significantly higher vitamin A content of sample A (100\% carrot juice) could be attributed to the higher beta carotene content in carrots.

Table 3. Mineral elements and vitamin composition of carrot-cucumber juice (mg/100 mL).

\begin{tabular}{ccccccc}
\hline Samples & Calcium & Magnesium & Phosphorous & Potassium & Vit C & Vit A \\
\hline A & $3.20 \pm 0.20^{\mathrm{a}}$ & $1.10 \pm 0.10^{\mathrm{b}}$ & $4.83 \pm 0.21^{\mathrm{a}}$ & $32.10 \pm 0.10^{\mathrm{a}}$ & $14.48 \pm 0.32$ & $5.28 \pm 0.15$ \\
$\mathrm{~B}$ & $2.15 \pm 0.10^{\mathrm{b}}$ & $0.13 \pm 0.03^{\mathrm{c}}$ & $4.81 \pm 0.18^{\mathrm{a}}$ & $31.10 \pm 0.10^{\mathrm{b}}$ & $21.07 \pm 0.26$ & $2.7 \pm 0.05$ \\
$\mathrm{C}$ & $1.37 \pm 0.06^{\mathrm{d}}$ & $0.16 \pm 0.00^{\mathrm{c}}$ & $4.81 \pm 0.15^{\mathrm{a}}$ & $26.50 \pm 0.10^{\mathrm{c}}$ & $24.48 \pm 1.11$ & $2.81 \pm 0.07$ \\
$\mathrm{D}$ & $1.71 \pm 0.10^{\mathrm{c}}$ & $0.17 \pm 0.03^{\mathrm{c}}$ & $3.40 \pm 0.10^{\mathrm{b}}$ & $21.40 \pm 0.10^{\mathrm{d}}$ & $17.71 \pm 0.35$ & $1.9 \pm 0.03$ \\
E & $1.60 \pm 0.11^{\mathrm{c}}$ & $1.40 \pm 0.10^{\mathrm{a}}$ & $2.40 \pm 0.10^{\mathrm{c}}$ & $14.70 \pm 0.10^{\mathrm{e}}$ & $15.54 \pm 0.42$ & $2.8 \pm 0.14$ \\
\hline
\end{tabular}

The data are presented as mean $\pm \mathrm{SD}$. The mean values in the same column with different superscript letters are significantly different $(p \leq 0.05)$. A $=100 \%$ carrot; B $=80 \%$ carrot, $20 \%$ cucumber; $C=70 \%$ carrot, $30 \%$ Cucumber; $\mathrm{D}=50 \%$ carrot, $50 \%$ cucumber and $\mathrm{E}=100 \%$ cucumber juice.

\subsection{Physicochemical Properties of the Juice}

Figure 1I-IV shows the physicochemical properties of the carrot-cucumber juice. The $\mathrm{pH}$ (Figure 1I) which ranged between 5.90 and 6.21 on the first day of production reduced to 5.20 and 5.70 after five days of storage. The gradual decline in $\mathrm{pH}$ towards acidity as the storage days progressed may be due to biochemical reactions taking place within the juice, particularly the fermentation process. This may be expected since the juices were only stored at refrigerated temperatures and no chemical preservative was used. The slight changes in the $\mathrm{pH}$ of sample E (100\% cumber juice) (5.94-5.70) compared to the $\mathrm{pH}$ of sample A (100\% carrot juice) (5.91-5.20) may be due to the higher percentage of sugar in carrots as indicated by the percentage Brix value (Figure 1III), hence a higher predisposition to fermentation. Therefore, in order to preserve the sensorial qualities of the juice, storage at freezing temperature may be explored or the length of storage at refrigerated temperature could be reduced. The reported $\mathrm{pH}$ of juices tends more towards an acidic $\mathrm{pH}$ range $[8,19]$, which may help in extending the shelf-life of the juice. This study also indicated that $\mathrm{pH}$ is indirectly related to total titratable acidity (TTA) (Figure 1II). The TTA values of the juices ranged between 0.02 and $0.03 \mathrm{mg} / \mathrm{g}$ on the first day of production to between 0.06 and $0.09 \mathrm{mg} / \mathrm{g}$ after five days of storage. Percentage Brix measures the soluble (sugar) content of juice. As expected, Figure 1III shows that cucumbers contain less sugar content $(3.51 \%)$ when compared to carrots $(7 \%)$. This is also reflected in the juice blends. 
Although there was no apparent significant difference between samples A, B and C, particularly on the first day of production, there were significant differences between these samples $(\mathrm{A}, \mathrm{B}$ and $\mathrm{C})$ and sample D, which contained equal proportions of carrot and cucumber juice, and sample E $(100 \%$ cucumber), which was obviously due to the lower sugar content in cucumbers. The $7 \%$ maximum Brix values obtained in this study (100\% carrot juice) are lower when compared to the 8 and 12\% obtained in a previous study for $100 \%$ watermelon and $100 \%$ orange juice, respectively [8]. Viscosity (Figure 1III) measures the ease of flow of the juices and it ranged between 0.24 and 0.87 Pa.s for the fresh samples to between 0.12 and 0.43 Pa.s after five days of storage. While there may be differences in the viscosity of the juices because of the type of raw material used, which may be influenced by the pulp content, the juices are generally liquids. The very low value of sample E may be expected, given the higher moisture content of cucumber compared to carrot. On the other hand, the higher sugar (Brix) content of the carrot juice might be responsible for the significantly higher viscosity of sample A. In addition, the gradual decline in the viscosity (sample A) may indicate liquefaction of the sugar due to fermentation. The obtained viscosity value for cucumber juice (0.12 Pa.s) is comparable to that reported for orange (0.1 Pa.s) and watermelon (0.2 Pa.s) juices, respectively [8].
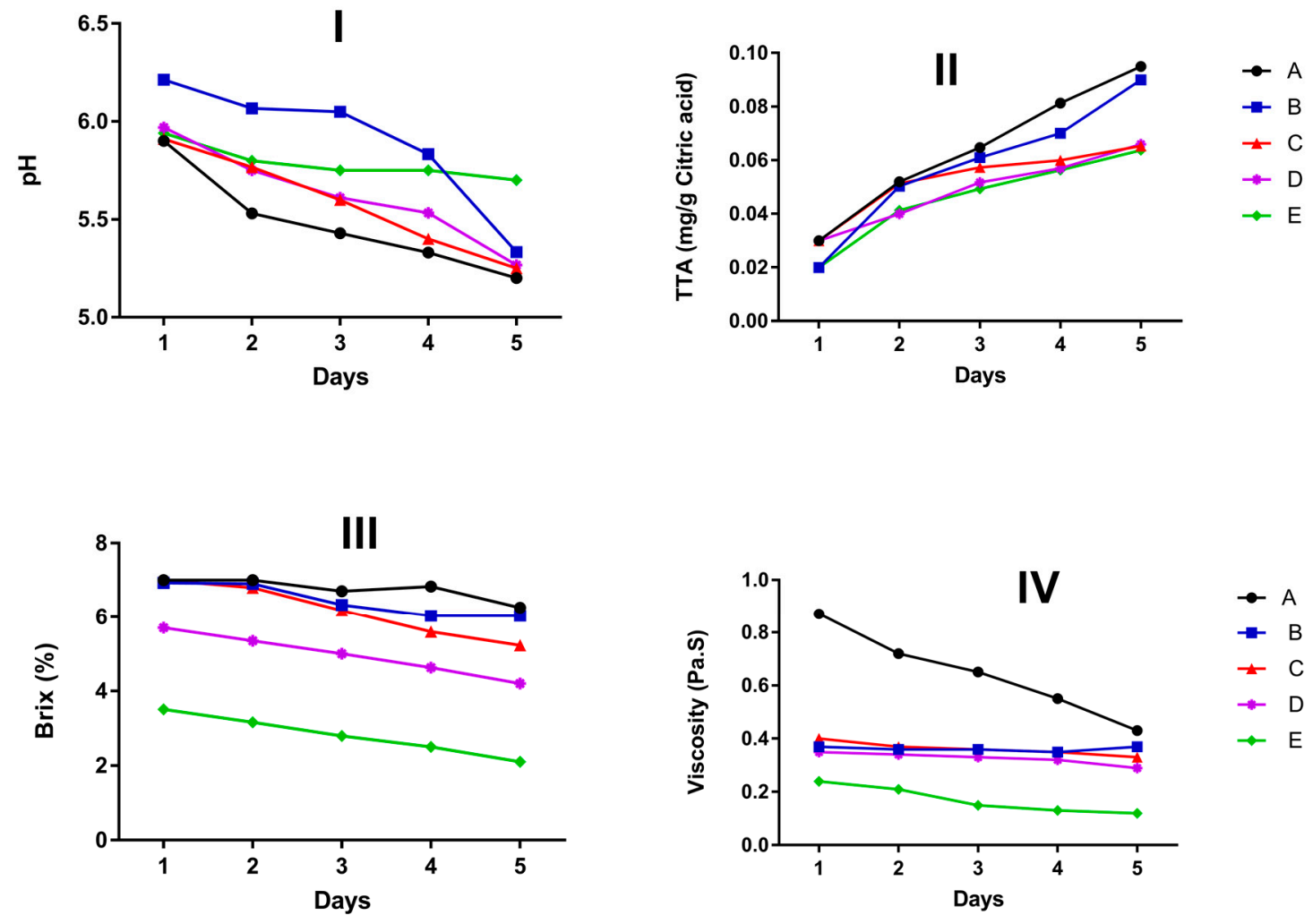

Figure 1. The $\mathrm{pH}$ (I), total titratable acidity (TTA) (II), Brix (III) and viscosity (IV) of carrot-cucumber juice.

\subsection{Phytochemical and Antioxidant Properties of Carrot-Cucumber Juice}

The potential of natural bioactive compounds to modulate diseases, including neurodegenerative, cardiovascular and other chronic diseases, has been the focus of many research studies $[8,20]$. Moreover, studies have indicated that long-term consumption of the bioactive components of plant sources may prevent or ameliorate the development and symptoms of cancer, diabetes, hypertension and osteoporosis [21-23]. Fruit and vegetables are rich sources of polyphenolic compounds such as the flavonoid, phenolic and tannin compounds. They are secondary metabolites in plants where they serve as a defense mechanism against external forces such as ultraviolet radiation and pathogens [21]. The total phenolic content (TPC) and total flavonoid content (TFC) of carrot-cucumber juice are shown 
in Figure 2I,II. Sample A (100\% carrot juice) showed a higher TPC as well as a higher TFC. However, this does not translate to better antioxidant properties through the free radical scavenging (DPPH) and ferric reducing assays (Figure 2III,IV) used in the current study to evaluate the antioxidant properties of the juice. Since polyphenolic compounds and their derivatives are diverse both in types and bioactivities, the observed trend in the current study might therefore be due to the bioactivity of the predominant polyphenolic derivative in the juice as well as the reaction parameters [24]. However, with the varied levels of the phytochemical (TPC and TFC) contents, that all the blended samples except sample C (FRAP assay) had comparable or better antioxidant properties may suggest improved bioactivity resulting from the synergistic effects of the different bioactive compounds in the blends [19]. In addition, that sample D (50:50) showed relatively better overall bioactivity may indicate that this ratio is the best blending ratio for the optimum antioxidative potential of the carrot-cucumber juice blend.
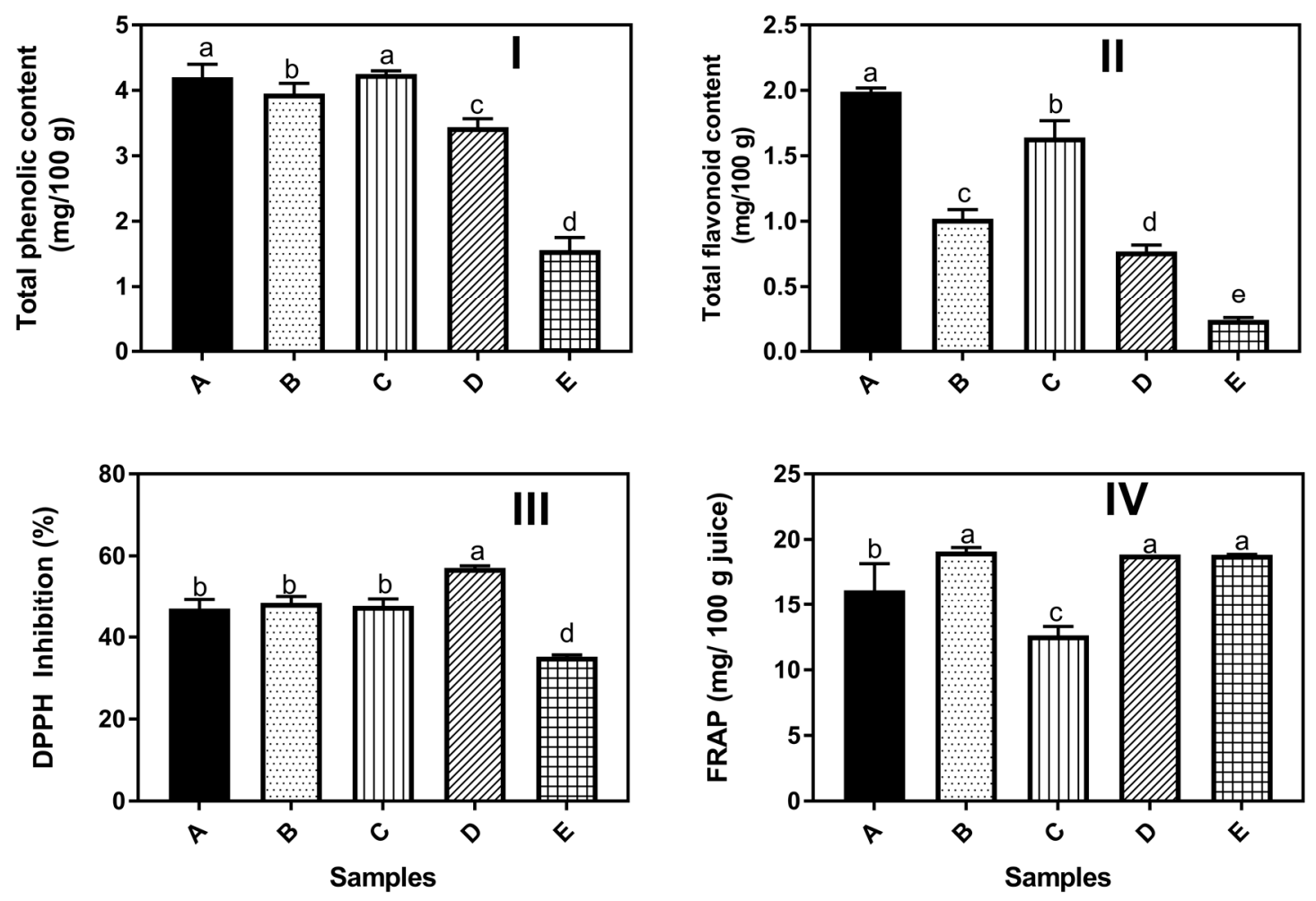

Figure 2. Total phenolic (I) and total flavonoid (II) content. The DPPH inhibition (III) and ferric reducing antioxidant power (IV) of carrot-cucumber juice.

\subsection{Sensory Properties of Carrot-Cucumber Juice}

Table 4 shows the evaluated results of the different sensory properties, namely, taste, appearance, aroma and mouthfeel, for the juices. The overall acceptability was taken as the average of the four parameters (taste, appearance, aroma and mouthfeel). The higher ratings for the taste, particularly in samples A and B (100 and $80 \%$ carrot content, respectively) may be due to the higher sugar content as revealed by the Brix content result (Figure 1III). Obviously, the bright orange color, impacted by beta carotene in carrots, is more appealing than the chlorophyll green color of cucumbers and hence higher preference for the carrot juice. The color of the juice is impacted by the various color producing phytochemicals, such as the carotenoids and chlorophylls in the fruit/vegetable $[25,26]$. This preference is also reflected in the gradual decrease in appearance ratings as the carrot content decreased. The discriminative effects of taste and appearance on the acceptability of beverages are well reported $[2,17,27,28]$. Although, there was no statistically significant difference, sample D (50:50) which, comparatively, showed better antioxidative properties (Figure 2III,IV) was poorly rated in 
taste, aroma, mouthfeel and hence in overall acceptability. A similar trend of poor ratings for samples with better antioxidative properties has also be reported $[17,27]$. In summary, while there were no statistically significant differences in the ratings, the overall acceptability results indicated that carrot juice was preferred due to the higher ratings.

Table 4. Sensory properties of carrot-cucumber juice.

\begin{tabular}{cccccc}
\hline Samples & Taste & Appearance & Aroma & Mouthfeel & Overall Acceptability \\
\hline A & $8.10 \pm 0.99^{\mathrm{a}}$ & $7.60 \pm 1.89^{\mathrm{a}}$ & $7.10 \pm 1.52^{\mathrm{a}}$ & $7.30 \pm 1.56^{\mathrm{a}}$ & $7.53 \pm 1.05^{\mathrm{a}}$ \\
B & $8.10 \pm 0.87^{\mathrm{a}}$ & $7.70 \pm 1.76^{\mathrm{a}}$ & $7.20 \pm 1.22^{\mathrm{a}}$ & $6.00 \pm 1.69^{\mathrm{a}}$ & $7.25 \pm 0.99^{\mathrm{a}}$ \\
C & $7.70 \pm 0.94^{\mathrm{a}}$ & $7.00 \pm 1.69^{\mathrm{a}}$ & $7.10 \pm 1.28^{\mathrm{a}}$ & $6.50 \pm 2.32^{\mathrm{a}}$ & $7.08 \pm 1.03^{\mathrm{a}}$ \\
D & $7.40 \pm 0.96^{\mathrm{a}}$ & $6.80 \pm 1.22^{\mathrm{a}}$ & $6.00 \pm 1.82^{\mathrm{a}}$ & $5.40 \pm 1.50^{\mathrm{a}}$ & $6.4 \pm 1.47^{\mathrm{a}}$ \\
E & $7.80 \pm 1.13^{\mathrm{a}}$ & $6.30 \pm 1.82^{\mathrm{a}}$ & $7.10 \pm 2.07^{\mathrm{a}}$ & $5.80 \pm 1.54^{\mathrm{a}}$ & $6.75 \pm 1.22^{\mathrm{a}}$ \\
\hline
\end{tabular}

The data are presented as mean $\pm \mathrm{SD}$. The mean values in the same column with different superscript letters are significantly different $(p \leq 0.05)$. A $=100 \%$ carrot; $\mathrm{B}=80 \%$ carrot, $20 \%$ cucumber; $\mathrm{C}=70 \%$ carrot, $30 \%$ Cucumber; $\mathrm{D}=50 \%$ carrot, $50 \%$ cucumber and $\mathrm{E}=100 \%$ cucumber juice.

\section{Conclusions}

This research work shows that carrots and cucumbers contain an appreciable amount of antioxidant properties, vitamins, minerals and macronutrients which are required for the proper functioning of the body. It is a known fact that carrot has a high composition of Vitamin A, therefore blending carrot and cucumber helped to increase the nutritional composition of cucumber juice. The study also revealed that blending of carrot and cucumber provided a better bioactivity (antioxidant properties) with the optimum bioactivity obtained at a 50:50 ratio when compared to the individual juice.

Author Contributions: Conceptualization, T.A.A.; Methodology, K.E.A.; Formal Analysis, K.E.A.; Writing-Original Draft Preparation, K.E.A.; Writing-Review \& Editing, T.A.A.; Visualization, T.A.A.; Supervision, T.A.A.

Funding: This research received no external funding.

Conflicts of Interest: The author declares no conflict of interest.

\section{References}

1. Banigo, E.B.; Kiin-Kabari, D.B.; Owuno, F. Physicochemical and sensory evaluation of soy/carrot drinks flavoured with beetroot. Afr. J. Food Sci. Technol. 2015, 6, 136-140.

2. Aderinola, T.A. Effects of pumpkin leaves on the chemical composition and antioxidant properties of smoothies. In Proceedings of the 4th Regional Food Science and Technology Summit (ReFoSTs), Akure, Nigeria, 6-7 June 2018; pp. 281-287.

3. Dias, J.S. Nutritional Quality and Health Benefits of Vegetables: A. Review. Food Nutr. Sci. 2012, 3, $1354-1374$. [CrossRef]

4. Bao, Ji.; Cai, Y.; Sun, M.; Wang, G.; Corke, H. Anthocyanins, Flavonols and Free Radical Scavenging Activity of Chinese Bayberry (Myrica rubra) Extracts and Their Color Properties and Stability. J. Agric. Food Chem. 2005, 53, 2327-2332. [CrossRef] [PubMed]

5. Okwori, E.; Onu, R.O.; Adamu, M.; Chindo, H.; Dikko, H.; Odunze, I. 1.; Baidu, A.L.; Natala, C.; Eze, P. Production and shelf life determination of fruit/vegetable juices using watermelon, cucumber, pineapple and carrot. Afr. J. Food Sci. Technol. 2017, 8, 34-39. [CrossRef]

6. Mullie, P.; Clarys, P. Association between Cardiovascular Disease Risk Factor Knowledge and Lifestyle. Food Nutr. Sci. 2011, 2, 1048-1053. [CrossRef]

7. El-abasy, A.E.; Abou-gharbia, H.A.; Mousa, H.M.; Youssef, M.M. Mixes of Carrot Juice and Some Fermented Dairy Products: Potentiality as Novel Functional Beverages. Food Nutr. Sci. 2012, 3, 233-239. [CrossRef]

8. Aderinola, T.A.; Adeniran, A.E.; Technology, A.; State, O. Effects of storage on physicochemical properties of orange-watermelon juice. Ann. Food Sci. Technol. 2015, 16, 326-332. 
9. Muhammad, S.; Saghir, A.S.; Saima, M. Role of sodium benzoate as a chemical preservative in extending the shelf life of orange juice. Glob. Adv. Res. J. Food Sci. Technol. 2013, 2, 7-18.

10. Emelike, N.J.T.; Ebere, C.O. Effect of packaging materials, storage conditions on the vitamin $\mathrm{C}$ and $\mathrm{pH}$ value of cashew-apple (Anacardium occidentale L.) juice. J. Food Nutr. Sci. 2015, 3, 160-165.

11. Association of Official Analyticl Chemists International. Official Methods of Analysis of AOAC, 19th ed.; AOAC: Gaithersburg, MD, USA, 2012.

12. Benderitter, M.; Maupoi, V.; Vergely, C.I.; Dalloz, F.; Briot, F.; Rochette, L. Studies by electron paramagnetic resonance of the importance of iron in the hydroxyl scavenging properties of ascorbic acid in plasma: Effects of iron chelators. Fundam. Clin. Pharcology 1998, 12, 510-516. [CrossRef]

13. Pearson, D.; Cox, H.E. Chemical Analysis of Foods. In Chemical Analysis of Foods, 7th ed.; Churchill Ligstone: Edinburg, Hidalgo; New York, NY, USA, 1976.

14. Nabavi, S.M.; Ebrahinzadeh, M.A.; Nabavi, S.F.; Jafari, M. Free radical scavenging activity and antioxidant capacity of Eryngium caucasium trautv and Froripia subpinnata. Pharmacologyonline 2008, 25, 19-25.

15. Braide, W.; Oranusi, S.U.; Otali, C.C. Nutritional, antinutritional, minerals and vitamin compositions of fourteen brands of fruit juice sold in Onitsha main market. J. Res. Basic Appl. Sci. 2012, 1, 16-18.

16. Olalude, C.B.; Oyedeji, F.O.; Adegboyega, A.M. Physico-Chemical Analysis of Daucus Carota (Carrot) Juice for possible industrial applications. J. Appl. Chem. 2015, 8, 110-113.

17. Aderinola, T.A. Nutritional, Antioxidant and Quality Acceptability of Smoothies Supplemented with Moringa oleifera Leaves. Beverages 2018, 4, 104. [CrossRef]

18. Dima, F.; Istrati, D.; Garnai, M.; Serea, V. Study on obtaining vegetables juices with high antioxidant potential, preserved by ohmic pasteurization. J. Agroaliment. Process. Technol. 2015, 21, 67-74.

19. Šic Žlabur, J.; Dobričević, N.; Pliestić, S.; Galić, A.; Bilić, D.; Voća, S. Antioxidant Potential of Fruit Juice with Added Chokeberry Powder (Aronia melanocarpa). Molecules 2017, 22, 2158. [CrossRef] [PubMed]

20. Aderinola, T.A.; Fagbemi, T.N.; Enujiugha, V.N.; Alashi, A.M.; Aluko, R.E. In vitro antihypertensive and antioxidative properties of trypsin-derived Moringa oleifera seed globulin hydrolyzate and its membrane fractions. Food Sci. Nutr. 2018, 0, 1-8. [CrossRef]

21. Pandey, K.B.; Rizvi, S.I. Plant polyphenols as dietary antioxidants in human health and disease. Oxid. Med. Cell. Longev. 2009, 2, 270-278. [CrossRef]

22. Graf, B.A.; Milbury, P.E.; Blumberg, J.B. Flavonols, flavonones, flavanones and human health: Epidemological evidence. J. Med. Food 2005, 8, 281-290. [CrossRef]

23. Arts, I.C.W.; Hollman, P.C.H. Polyphenols and disease risk in epidemiologic studies. Am. J. Clin. Nutr. 2005, 81, 317-325. [CrossRef]

24. Jang, H.D.; Chang, K.S.; Huang, Y.S.; Hsu, C.L.; Lee, S.H.; Su, M.S. Principal phenolic phytochemicals and antioxidant activities of three Chinese medicinal plants. Food Chem. 2007, 103, 749-756. [CrossRef]

25. Zinoviadou, K.G.; Galanakis, C.M.; Brn, M.; Grimi, N.; Boussetta, N.; Mota, M.J.; Saraiva, J.A.; Patras, A.; Tiwari, B.; Barba, F.J. Fruit juice sonication: Implications on food safety and physicochemical and nutritional properties. Food Res. Int. 2015, 77, 743-752. [CrossRef]

26. Barba, F.J.; Cortés, C.; Esteve, M.J. Study of Antioxidant Capacity and Quality Parameters in An Orange Juice-Milk Beverage After High-Pressure Processing Treatment. Food Bioprocess Technol. 2012, 5, 2222-2232. [CrossRef]

27. Nowicka, P.; Wojdy, A.; Samoticha, J. Sensory attributes and changes of physicochemical properties during storage of smoothies prepared from selected fruit. LWT_Food Sci. Technol. 2016, 71, 102-109. [CrossRef]

28. Wang, S.; Lin, T.; Man, G.; Li, H.; Zhao, L.; Wu, J.; Liao, X. Effects of Anti-browning Combinations of Ascorbic Acid, Citric Acid, Nitrogen and Carbon Dioxide on the Quality of Banana Smoothies. Food Bioprocess Technol. 2014, 7, 161-173. [CrossRef]

(C) 2019 by the authors. Licensee MDPI, Basel, Switzerland. This article is an open access article distributed under the terms and conditions of the Creative Commons Attribution (CC BY) license (http:// creativecommons.org/licenses/by/4.0/). 